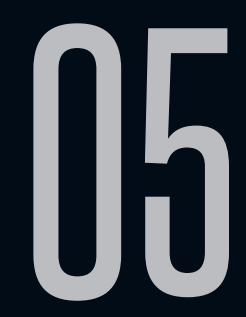

\title{
O REAL E SEUS TRUQUES: O EFEITO FANTÁSTICO EM THE PRESTIGE, DE CHRISTOPHER NOLAN
}

Abílio Aparecido Francisco Junior (UEL)

Adilson dos Santos (UEL)

Recebido em 09 fev 2018. Aprovado em 30 mai 2018.
Abílio Aparecido Francisco Junior é Mestrando pela Universidade Estadual de Londrina. UEL-PGCAPES. Mestrado em Literatura Comparada. Áreas de interesse: Fantástico; Estranho; Maravilhoso; Insólito. Lattes: http://lattes.cnpq.br/8596224888723273. E-mail: abilio.jr26@gmail.com

Adilson dos Santos é Doutor em Letras pela Universidade Estadual de Londrina - UEL. Professor efetivo de Teoria da Literatura e Literatura Brasileira e docente permanente do Programa de Pós-Graduação em Letras: Estudos Literários na Universidade Estadual de Londrina - UEL. Membro do GT "Vertentes do Insólito Ficcional", da ANPOLL - Associação Nacional de Pós-Graduação e Pesquisa em Letras e Linguística. Áreas de interesse: Maravilhoso; Fantástico; Estranho; Realismo Maravilhoso ou Mágico; Neofantástico. Lattes: $\quad$ http://lattes.cnpq.br/4749164793037145. E-mail: adilson.letras@yahoo.com.br

Resumo: O presente trabalho tem como objetivo investigar a presença do "efeito fantástico" no filme The Prestige (2006), de Christopher Nolan. A partir de pesquisadores do fantástico, como David Roas (2014) e Filipe Furtado (1980), como também de 
Roland Barthes, em seu ensaio "O efeito de real" (1968), verificar-se-ão as ferramentas utilizadas por Nolan para construir um efeito de suspensão no espectador. Tal efeito tem o intuito de causar a hesitação - tão importante para a configuração do fantástico na narrativa - no receptor de sua obra, fazendo com que o observador seja conduzido pelo caminho que o diretor quer que ele siga. Assim, a partir de cortes, da ambientação, do desenvolvimento psicológico dos personagens, entre outros, tem-se a construção do efeito fantástico durante todo o filme de Christopher Nolan.

Palavras-chave: Christopher Nolan; Fantástico; The Prestige; Real.

Abstract: This paper aims at investigating the presence of the "fantastic effect" in the film The Prestige (2006), by Christopher Nolan. Based on the researchers of the fantastic, such as David Roas (2014) and Filipe Furtado (1980), as well as Roland Barthes, in his essay "The reality effect" (1968), we will verify the tools used by Nolan to build a suspension effect on the viewer. Such effect is intended to cause the hesitation - so important to the configuration of the fantastic in the narrative - in the receiver of his work, causing the observer to be led along the path that the director wants him to follow. Thus, from cuts, the setting, the psychological development of the characters, among others, one has a construction of the fantastic effect throughout Christopher Nolan's film.

Keywords: Christopher Nolan; Fantastic; The Prestige; Real.

\section{A ILUSÃO E O CINEMA}

O surgimento do cinema como ficção está intrinsecamente ligado à mágica de palco, e isso se mostra evidente na carreira de Georges Méliès. Primeiramente mágico de palco, Méliès, 
seguindo os passos do famoso Houdini, fez do ilusionismo sua profissão. Isso se deu até assistir à notória apresentação do cinematógrafo dos irmãos Louis e August Lumière, em 1895, no Grand Cafe do Boulevard des Capucines, e ficar arrebatado com a "mágica" do cinematógrafo ao reproduzir uma sequência de frames (quadros) rapidamente, causando espanto nos espectadores ali presentes, por acharem que seriam atingidos pelo trem o qual era mostrado chegando à estação. Méliès tentou comprar o maquinário dos irmãos Lumière, mas estes não quiseram vendê-lo. No entanto, isso não foi suficiente para deter o mágico, que começou a procurar formas de reproduzi-lo, finalmente comprando um teatrógrafo de Robert William Paul e fazendo ajustes para aproximar tal maquinário do pretendido (SANTOS, 2012).

De acordo com as ideias de Hilario Junior dos Santos (2012), o ilusionista francês começou a usar o equipamento como complementação de seus truques nas apresentações, criando atrativos nunca vistos antes e que prendiam a atenção dos espectadores. Porém, Méliès percebeu que podia fazer muito mais com aquele equipamento e todo seu conhecimento de mágica de palco. Assim, surgiram os efeitos especiais no cinema e muitos outros mecanismos que seriam aprimorados no futuro. Para o propósito deste trabalho, é pertinente citar o cut (corte). A partir das elipses temporais proporcionadas pelo uso do corte nas gravações, Méliès percebeu as possibilidades inimagináveis que poderia explorar ao fazer uso desse elemento e ao uni-lo com o campo da Arte, tomando por base as suas experiências no palco, o que se mostrava bem mais promissor se comparado aos irmãos 
Lumière, que viam futuro para sua invenção muito mais no campo da História e da Ciência (SANTOS, 2012).

Em um de seus filmes mais famosos, Le Voyage dans la Lune (no Brasil, Viagem à Lua), de 1902, Méliès conseguiu adaptar, a partir das obras de Júlio Verne e H. G. Wells, e, assim, dirigir/produzir a primeira ficção científica feita na história do cinema, de Acordo com Santos (2012). Os figurinos, os cenários e o uso de truques de mágica de palco unidos ao corte do cinema promoveram uma experiência única no espectador da época, criando uma forma de ilusão coletiva em todos que presenciaram aquele momento. Percebe-se, assim, que os avanços científicos tiveram um papel fundamental no surgimento do cinema, mas, para que ele fosse visto como um objeto artístico, foi necessária a união desse progresso com a arte milenar da enganação do ilusionismo, conferindo um certo tipo de poesia ao processo fílmico com o processo criativo do cineasta.

Orson Welles, em 1973, também inovou na indústria cinematográfica, ao trabalhar com o conceito de filme-ensaio. F for Fake (no Brasil, Verdades e Mentiras), principalmente a partir da colagem, criou um labirinto a ser desvendado pelo espectador ao brincar com o conceito de autoria no campo da arte e, ao mesmo tempo, o próprio conceito de realidade dentro do cinema. Logo no início do filme, vemos o próprio Welles realizando truques de mágica para uma criança em uma estação. Nesse filme, que se propõe documentário, somos informados pelo diretor que sua temática será a de mentiras. Temos três personagens que podem ser consideradas principais, pois cada uma tem um foco narrativo e uma história a ser contada ao longo dos 90 minutos. Certo desconforto com relação à obra toma conta do espectador ao 
descobrir que o filme tratará da história de dois falsificadores. Entre as personagens, está uma mulher que, em um primeiro momento, só será mostrada andando pela rua atraindo olhares lascivos. Sua história será relatada somente ao final do filme.

Com essas ferramentas, Welles cria uma montagem labiríntica entre as três personagens ao produzir uma sensação de desconforto e insegurança no espectador. Isso ocorre por conta das parcas formas de identificar quando acontece uma transição entre linhas narrativas da história, além de ser custoso estabelecer uma temporalidade precisa dos acontecimentos antes do final do filme. Dessa forma, assim como a criança no início do filme era enganada pelo truque de mágica de Welles, o espectador, ao longo dos 90 minutos, precisa se questionar a todo o momento para tentar descobrir se não está sendo manipulado e iludido. Portanto, da mesma forma que Méliès ousou com a técnica do corte e da montagem, Orson Welles também o faz, reforçando mais uma vez o caráter ilusório do cinema a partir de uma narrativa construída de forma fragmentada e que tem como objetivo deixar o espectador em suspense. Do mesmo modo, essa testemunha da história ali contada se mantém com a dúvida sobre a veracidade do que acabou de assistir, mesmo após o filme se encerrar. Esse estado de suspensão em que o espectador é colocado funciona, principalmente, para levá-lo a questionar o que é real e o que é falso, não apenas naquele filme, mas na indústria cinematográfica, propondo, talvez, uma nova forma de analisar a própria arte.

Nessa mesma linha de pensamento está Christopher Nolan. Sua filmografia é repleta de obras que possibilitam a discussão do real e do cinema: como em Memento (no Brasil, Amnésia), em 2000, por 
meio do uso da reconstrução da memória; em Inception (no Brasil, A Origem), em 2010, por meio de uma mise en abyme de sonhos; e, principalmente, em The Prestige (no Brasil, O Grande Truque), em 2006, por meio de uma junção desses dois recursos já indicados junção essa que constitui nosso objeto de estudo neste trabalho. Ao fazer uso dos "cortes mágicos" de Méliès e da montagem ilusória de Welles, Nolan converge toda a discussão até aqui apresentada em um único lugar: seu filme de 2006, The Prestige.

\section{A MANIPULAÇÃO DE CHRISTOPHER NOLAN}

The Prestige se passa em Londres, na virada do século XIX para o XX. O filme conta a história de dois mágicos rivais, Alfred Borden (Christian Bale) e Robert Angier (Hugh Jackman), que passam a vida tentando um superar o outro com novos truques de mágica. Após se desenvolverem juntos como mágicos sob orientação do mesmo mestre e enfrentarem as mortes trágicas das esposas, das quais culpam um ao outro, passam a dedicar a vida à destruição do outro. A obsessão se torna tão intensa que chega a causar a morte dos dois personagens. É possível traçar essa narrativa em uma linha cronológica e, por que não, considerá-la um clichê. Quantas não são as obras de terror, até mesmo dramas, principalmente no cinema, que versam sobre uma rivalidade tão acirrada em que os protagonistas acabam se matando ao final? Porém, Christopher Nolan remodela essa história fazendo uso de uma série de recursos cinematográficos e narrativos, partindo de cortes em momento oportuno e do baralhamento de fatos ocorridos durante o filme.

As primeiras cenas do filme são extremamente significativas para o decorrer da história. O espaço é apresentado como uma 
floresta silenciosa, coberta por uma neblina, com a câmera registrando diversas cartolas iguais enquanto o título do filme é exibido no centro da tela. Ao mesmo tempo, uma narração off, em que não se sabe se é dirigida ao espectador, explica os três passos de um truque de mágica. Enquanto essa narração é realizada, há uma transição de cenas e podemos ver, agora, um senhor que, à frente na narrativa, saberemos ser o dono da voz, Cutter (Michael Caine), durante o tempo em que este desempenha um truque de mágica para uma criança, que descobriremos ser a filha de Alfred Borden. Vale ressaltar a grande semelhança com o início de $F$ for Fake, de Orson Welles, no qual o cineasta realiza truques de mágica para uma criança. Dessa forma, ocorrem as primeiras, de muitas, enganações do filme. Por estar sincronizada com o que ocorre na cena do truque de mágica e entrecortada com a cena do assassinato de Robert Angier, pensamos que a narração de Cutter está sendo usada para explicar esses quadros, mas, quando se troca novamente de cena, descobrimos que essa narração era derivada do julgamento de Borden, enquanto Cutter explicava ao juiz os três passos para um truque de mágica.

A importância do corte no filme é mostrada nessa primeira sequência de cenas. Verifica-se: (1) Floresta com várias cartolas; (2) Vários pássaros idênticos mostrados em gaiolas, enquanto Cutter pega um deles para realizar o truque de mágica para a filha de Borden; (3) Angier faz a a presentação de seu truque enquanto Borden tenta descobrir como ele o realiza; (4) Cutter sendo interrogado no tribunal. As três primeiras cenas descritas são todas "retiradas" de momentos mais avançados do filme, porém, gerando um efeito diferente daquele do início. Essa montagem - podemos pensar até 
como uma colagem do próprio filme - funciona de modo a suscitar um sentimento essencial para a economia da obra: a expectativa. A obra passa grande parte do tempo gerando expectativas no público, brincando com sua capacidade de preencher lacunas, enquanto apresenta informações cortadas, isto é, somente aquilo que ele deve ver. Neste momento, já percebemos a inevitável relação do filme com o truque de mágica, no qual um mágico deve desviar a atenção dos espectadores para poder realizar seu truque de ilusão. Isso fica bem evidente em um trecho da narração de Cutter: "Você está procurando o segredo, mas não vai encontrar. Porque não está realmente olhando. Você não quer saber, na verdade. Você quer ser enganado" (00:02:33-47).

Santos (2012), em seu artigo intitulado "O mágico cineasta e o prestígio: narrativa, metalinguagem e tecnologia no cinema espetáculo" aborda as diversas relações que podem ser estabelecidas a partir das possíveis interpretações da obra:

No caso deste filme, decorre uma reflexão sobre o próprio espetáculo do Cinema como arte, como tecnologia, como narrativa e mesmo como Filosofia, pois remonta, inclusive, o "Mito da Caverna" de Platão e sua relação com o tipo de espetáculo compartilhado por uma audiência disposta a participar de um jogo de ilusão coletivo, premeditado e aceito, como é o caso da mágica de palco ou da projeção cinematográfica. (2012, p.2)

O "jogo de ilusão coletivo" citado pelo autor se destaca neste ponto de nosso trabalho, visto o papel fundamental das ferramentas cinematográficas para que o filme não se transforme em um clichê. Aqui, cabe retomar as artimanhas 
de Georges Méliès com o surgimento do cinema, visto que a história do filme se passa na transição entre os séculos XIX e $X X$, representando o avanço tecnológico com as invenções de Nikola Tesla. Apesar da questão do surgimento do cinema não ser diretamente tratada no filme, é possível perceber certa relação com um de seus criadores, já que Thomas Edison é citado ao longo da obra tentando roubar as ideias de Tesla. Na história do filme, a tecnologia tem um papel fundamental ao ser considerada "real magic" (mágica real), porém não passa do avanço científico hiperbolizado na figura de Tesla.

O uso do roteiro não linear, de flashbacks, de montagem, da fotografia, e até da maquiagem, são artifícios utilizados por Nolan em seu filme para proporcionar o jogo de espelhos de um truque de mágica. Porém, tais expedientes serão, por nós, tratados posteriormente. Há, também, o uso da narrativa em cascata. Como em Inception, The Prestige trabalha com a mise en abyme como recurso para produzir a ilusão. A este respeito, Bordwell e Thompson (Apud ALVAR, 2017, p.136) afirmam: "The plot shuffles story order, plays with levels of knowledge, replay some scenes, and cuts off others, withholding their consequences [to misdirect] our attention"1. Isto posto, verifica-se, tanto no filme aqui analisado quanto nas outras obras do diretor, que há certa consonância por trás de todos seus roteiros, como afirma Batista (2012, p. 87) em sua dissertação sobre o cinema de Christopher Nolan:

Os filmes de Nolan compartilham a ideia de que não existe uma realidade concreta que é acessível

1 Tradução: A trama mistura a ordem da história, brinca com níveis de conhecimento, repete algumas cenas, corta outras, retendo suas consequências [para desviar] nossa atenção (tradução nossa). 
igualmente a todos. Suas obras apontam para o fato de que todos, de algum modo concebem e constroem a realidade ao seu modo, adulterando ou relativizando muitas verdades concretas e até mesmo fabricando as suas próprias verdades de modo que a realidade passe a atender suas demandas, suas expectativas, de conformá-la à percepção de mundo e de si mesmos que possuem.

Todd McGowan (2007, p.15) também corrobora a ideia de Batista, destacando o poder criativo do truque de mágica: "By causing an object to disappear and then reappear, magic, like all art, attests to the existence of a hole in the world, a gap in the structure of signification" ${ }^{2}$. Tal ideia é recorrente nos filmes de Nolan, sempre com protagonistas perturbados, seja pela morte dos pais (Batman), seja pela morte da esposa (Cobb, Angier, Leonard), seja até pela escassez de alimentos na terra (Coopper). Por conta desses traumas, tais personagens são convidadas a preencher a lacuna deixada em suas vidas com elementos fora da realidade cotidiana, como a luta ao crime na trilogia Batman, a incansável perseguição do assassino da esposa em Memento (no Brasil, Amnésia, 2000), os diversos truques de mágica em The Prestige, a intrusão em sonhos em Inception, e a viagem espacial para um planeta distante em Interstellar (no Brasil, Interestelar, 2014).

Por fim, um último ponto importante para o nosso trabalho se faz presente na relação entre a narrativa clássica e os atos de um truque de mágica indicados pelo filme. O primeiro ato, no filme chamado "The pledge" (A promessa), assemelha-se, em uma narrativa, à apresentação do cenário e dos personagens, além da 
indicação da motivação, todos vistos como detalhes importantes para o início de uma história. No filme, tal questão é indicada a partir da apresentação "ao público de algo normal, corriqueiro, compreensível ou relacionável com conceitos culturais da audiência [...] Dessa forma, a plateia se apega ao personagem do evento, normalmente o protagonista" (SANTOS, 2012, p.10).

O segundo ato, no filme chamado "The turn" (A virada), é indicado por Cutter como esse algo normal que se transforma em extraordinário, exemplificado com a ideia de fazer um objeto ou alguém desaparecer na mágica. Na narrativa, segundo Santos (2012, p.10), "é aqui que reside o fantástico, o diferente, o acaso, o acidente, o fora do normal". Enfim, o último ato da narrativa é apresentado como a solução, a renovação. Santos (2012) comenta sobre a tragédia grega, em que há o sacrifício do herói para um bem maior, o que difere da narrativa moderna, em que o sucesso ocorre quando o herói sobrevive, pronto para voltar ao seu cotidiano. No contexto do filme, esse terceiro ato é apresentado como The prestige (O prestígio): em uma tradução livre, "O aplauso". É nesse momento que, no truque de mágica, o objeto que desapareceu deve reaparecer, são e salvo, e, na trama do filme, "o personagem da ação dramática volta ao início e, por ter superado as intempéries, recebe reconhecimento, a coroa do sucesso, a admiração de quem presenciou suas dificuldades" (SANTOS, 2012, p.11).

Fica claro, portanto, que o cinema de Christopher Nolan possui grande possibilidade de análise sob diversas óticas, o que se mostra evidente principalmente pelas análises teóricas já existentes em torno de sua obra a partir dos mais variados vieses, como é o caso de McGowan (2007), Batista (2012) e Alvar (2017). Portanto, procura- 
se, neste trabalho, aprofundar a análise do filme The Prestige sob o viés da teoria do fantástico, principalmente aquela organizada por David Roas (2014) e Filipe Furtado (1980), sob a ótica da influência que o real e sua ilusão têm nessa linha de pesquisa. Para dar conta de abordar o campo do real que nos interessa, far-se-á uso, também, da teoria de Roland Barthes, como veremos a seguir.

\section{O EFEITO FANTÁSTICO E OS DESDOBRAMENTOS DO REAL}

Quando se trata do fantástico, há uma ideia comum equivocada de associá-lo ao ilógico, à fuga da razão e ao onírico. Tal compreensão, de certa forma, prejudica sua análise, visto que o coloca em território de contraposição ao real. Apesar de o campo de estudo do fantástico ser consideravelmente recente e ainda trazer muitas dissonâncias entre seus teóricos, há uma característica que se sobrepõe e se faz sentir praticamente em todos os estudos sobre tal categoria: o choque entre elementos sobrenaturais e reais no texto ficcional. Tal embate, na maioria dos casos, tem como objetivo causar a dúvida - ou como diria Todorov, a hesitação - no leitor sobre aquilo que ele está lendo. Dessa forma, em oposição à ideia comum aqui indicada, somos levados a concordar com David Roas (2014, p.51): "O realismo se converte assim em uma necessidade estrutural de todo texto fantástico".

Assim dito, fica claro que o texto fantástico, de modo particular, necessita firmar um pacto com o leitor para que tenha sucesso em seu objetivo. Nesse sentido, o pacto ficcional estabelecido entre o texto e o leitor do conto fantástico precisa, em um primeiro momento, de uma receptividade por parte desse leitor no sentido de consentir que os acontecimentos que serão narrados realmente 
ocorreram. O leitor necessita estar preparado para todo tipo de inconsistência relacionada à sua concepção de realidade. Até este ponto, o pacto ocorrido no texto fantástico varia pouco daquele realizado em qualquer outro tipo de texto ficcional. É precisamente a quebra de expectativa que mudará esse cenário.

O relato fantástico, ao apresentar ambientação e descrição completamente fiéis aos moldes do real já conhecido, "viola" o pacto estabelecido, muitas vezes ao surpreender o leitor pela carga de real que é veiculada na narrativa. O receptor, estranhando, espera a todo momento algo de insólito acontecer. Mas, quando isso acontece, o leitor é exposto ao fenômeno de forma tão sutil - e novamente inesperada - que não sabe mais no que acreditar. Ele não consegue se decidir entre o real que lhe foi apresentado de forma tão convincente - e com o qual já é acostumado - e o sobrenatural, o qual, por mais chocante que possa ser, é apresentado contendo frinchas, questões a serem resolvidas, parecendo incompleto. Assim, a narrativa fantástica se constrói a partir de uma dupla quebra de expectativa do leitor com o texto fantástico - quebra essa proporcionada, principalmente, pela construção mais verossímil possível do real.

No entanto, o "efeito fantástico" não ocorre somente na relação entre o leitor e o texto, mas também no nível intradiegético. As personagens, na narrativa fantástica, também precisam ter essa percepção de real. Roas, no subcapítulo "O fantástico como desestabilização do real: elementos para uma definição", em sua obra A ameaça do fantástico, corrobora essa visão ao apontar que "depois de aceitar (pactuar) que estamos diante de um texto fantástico, ele deve ser o mais verossímil possível para alcançar 
seu correto efeito sobre o leitor (a ilusão do real que Barthes denominou efeito de realidade)" (ROAS, 2014, p.51). Assim, somos levados a tentar entender certas características intrínsecas à narrativa fantástica:

Diferentemente de um texto realista, quando nos deparamos com uma narrativa fantástica essa exigência de verossimilhança é dupla, uma vez que devemos aceitar - acreditar em - algo que o próprio narrador reconhece ou estabelece, como impossível. $E$ isso se traduz em uma evidente vontade realista dos narradores fantásticos, que tentam fixar o narrador na realidade empírica de um modo mais explícito que os realistas. (ROAS, 2014, p.51-52)

Ao destacar tal efeito de realidade como uma ilusão do real, Roas consegue definir exatamente a importância do estudo de Barthes para a narrativa fantástica. A ilusão criada por meio daquele "efeito de real" se estabelece como fundamental a qualquer narrativa fantástica que cria a dúvida no leitor ou no campo da diegese. Isto posto, verifica-se a importância da verossimilhança para o texto fantástico, que é constituído, como afirmou Roas, por efeitos de realidade mais acentuados que aqueles dos próprios textos do período realista.

Barthes (2004, p.181), em seu ensaio intitulado "O efeito de real", ao indicar o barômetro de Flaubert e a porta de Michelet, exibe os "detalhes 'supérfluos"” relacionados à estrutura de um texto a partir de uma visão estrutural. No mesmo parágrafo em que tal questão é apresentada, esses "detalhes" também são apresentados como "'enchimentos' (catálises), afetados de um valor funcional indireto". Curiosamente, Barthes, no parágrafo seguinte de seu ensaio, trata 
dessas questões utilizando a expressão "pormenores 'inúteis"” (2004, p.182), o que é, claramente, uma ironia à suposta inutilidade desses detalhes. Por fim, o autor ainda indica tais "notações" do real como "escandalosas" (do ponto de vista da estrutura), deixando claras as duas vertentes que estão sendo trabalhadas no início de seu texto. Uma é a estruturalista, corrente que o autor ajudou a fundar e dedicou grande parte de sua vida, entendendo tais detalhes como escandalosos e pormenores supérfluos. $O$ teórico francês faz uso das ideias do pós-estruturalismo, corrente à qual pertencia na época de publicação do referido texto, $\mathrm{E}$ é também essa visão que acompanhará o restante de seu estudo.

É importante destacar essa trajetória tomada pelo crítico, visto que as duas correntes diferem muito entre si e, como o próprio Barthes expõe, seria impossível para o pensamento estruturalista considerar tais "pormenores" como algo passível de análise. Já numa perspectiva pós-estruturalista, "tudo, na narrativa, seria significante, e senão, se subsistem no sintagma narrativo alguns intervalos insignificantes, qual é, definitivamente, se assim se pode dizer, a significação dessa insignificância?" (BARTHES, 2004, p.184).

Ao estabelecer a descrição como "externa" à estrutura geral da narrativa, Barthes declara o caráter daquela como somatório, não se envolvendo diretamente nos conflitos desencadeados por esta. Assim, busca-se refletir sobre o trecho supracitado. Se considerarmos que $\mathrm{o}$ texto fantástico necessita de elementos que suspendam $\mathrm{o}$ leitor na dúvida entre o real e o sobrenatural, ou que nos textos realistas de Flaubert e Michelet busca-se atestar a tentativa de representação do real, somos levados e entender o "efeito" que esse real - caracterizado como pormenor - provoca no texto literário. Ele 
destaca, de certa forma, a autoridade ali presente. A "significação da insignificância" está dada por meio de elementos que corroboram com a construção de uma narrativa crivel, verossímil aos olhos de um leitor, seja ele desconfiado ou não.

Barthes estipula duas vantagens decorrentes do que ele chama de "chassé-croisé", uma mistura das injunções estéticas e referenciais na narrativa. A primeira alude à função estética, a dar sentido ao texto, considerando, principalmente, a descrição como essencial. A segunda interessa mais à nossa reflexão. De acordo com o autor, "por outra parte, colocando o referente como real, fingindo segui-lo de maneira escrava, a descrição realista evita deixar-se levar por uma atividade fantasística (precaução que se julgava necessária à 'objetividade' do relato)" (BARTHES, 2004, p.187). Contrapondo o trecho destacado, somos levados a pensar que a narrativa fantástica - aquela que causa dúvida no leitor -, antes mesmo dos textos realistas a que Barthes faz menção, fez uso desses pormenores supérfluos a fim causar o efeito fantástico aqui já mencionado, principalmente por meio de obras publicadas no início do século XIX por autores como E. T. A. Hoffmann, Prosper Mérimée, Théophile Gautier e Mary Shelley, entre outros.

Ao discutir sobre o "real concreto" e os "resíduos irredutíveis da análise funcional" (2004, p.187), o teórico francês expõe a aparição do real como forma de resistência à estrutura no texto ficcional, mas demonstra sua total importância na narrativa histórica: "o 'real concreto' torna-se justificativa suficiente do dizer" (2004, p.188). Assim, percebe-se que o discurso fantástico, como a narrativa histórica, faz uso desse "real concreto" e pressupõe que a mera representação do real - a descrição que tenta fazer referência à 
realidade de um leitor - se torna suficiente para que este acredite, seja momentaneamente, seja durante toda a narrativa, que aquele real representado é verossímil.

Portanto, identifica-se que, para Barthes, o real, por mais irrepresentável que possa ser, ainda possui seus graus de aparição no texto literário, e é por meio do "efeito de real" que a realidade se torna demonstrável - não representável - ao leitor, permitindo que esse identifique-se com o texto e faça associações com elementos baseados em seu conhecimento de mundo. Tais ideias ficam evidentes nos parágrafos finais do texto de Barthes, dos quais reproduzimos um trecho:

A verdade dessa ilusão [referencial] é a seguinte: suprimido da enunciação realista a título de significado de denotação, o "real" volta a ela a título de significado de conotação; no momento mesmo em que se julga denotarem tais detalhes diretamente o real, nada mais fazem, sem o dizer, do que significá-lo; o barômetro de Flaubert, a pequena porta de Michelet afinal não dizem mais do que o seguinte: somos o real; é a categoria do "real" (e não os seus conteúdos contingentes) que é então significada; noutras palavras, a própria carência do significado em proveito só do referente torna-se o significante mesmo do realismo: produz-se um efeito de real, fundamento dessa verossimilhança inconfessa que forma a estética de todas as obras correntes da modernidade. (2004, p.189-190)

Além de Roas (2014) considerar o sobrenatural como elemento desestabilizador do real, proporcionando o fantástico, há outros teóricos que seguem essa linha de pensamento e se aprofundam 
ainda mais na importância do real para manutenção da dúvida criada entre o sobrenatural e o seu contrário. É o caso de Filipe Furtado que, em sua obra A construção do fantástico na narrativa (1980), dedica um capítulo inteiro, intitulado "A falsidade verosímil", para dissertar sobre a importância desse real na narrativa fantástica e como ele é construído. Assim, para o crítico português, o fantástico está, a todo instante, falseando a imagem do real construída na narrativa. Tal questão fica evidente na seguinte passagem:

Pretendendo encenar a manifestação meta-natural irrompendo ou insinuando-se no quotidiano e tornar aceitáveis ambos esses elementos de facto antinómicos, o fantástico, mais do que qualquer outro género, procede por falsificação, escamoteando ou alterando dados necessários à decisão do destinatário do enunciado e procurando induzi-lo a uma cognição tão vaga e insegura quanto possível. (FURTADO, 1980, p.44)

Deste modo, esse destinatário do texto fantástico, para o teórico português, é conduzido "quase que pela mão" (1980, p.44) a "quase aceitar" a subversão às leis do mundo que lhe é familiar. Tal processo, pensando na ideia de ilusão, assemelha-se a um truque de mágica. Enquanto o espectador - leia-se leitor - é distraído por "efeitos de real" que brincam com suas expectativas e estabelecem um mundo ao qual ele está acostumado, por trás dos bastidores, a outra mão manipula acontecimentos que, de certa forma, Ihe são invisíveis, utilizando-se apenas de sugestões de algo extraordinário para manter sua atenção presa ao número.

Furtado se destaca na análise do real principalmente por conta de um conceito desenvolvido em sua obra. Para o teórico português, 
os "efeitos de real" aqui destacados são representados como um "recurso à autoridade", conforme se pode notar no trecho a seguir:

Na sua maioria, os processos aqui envolvidos têm por base o que se pode denominar recurso à autoridade. Em grande número de casos, com efeito, a narrativa procura atestar a realidade objectiva daquilo que encena com dados fictícios ou manipulados, mas atribuindo-os a fontes vulgarmente consideradas de grande confiança e probidade. Para tal, socorre-se com frequência de diversos meios, sobretudo o testemunho de certas personagens caracterizadas pelo seu prestígio, o apoio confirmativo prestado por documentos de vária índole, a referência enganadora a dados imaginários entretecidos com outros reconhecidamente verídicos ou, ainda, a distorção fraudulenta destes últimos. (FURTADO, 1980, p.54)

Da mesma forma que Furtado, Peter Penzoldt, em The supernatural in fiction, também destaca essa luta do leitor ao vacilar entre a ocorrência do sobrenatural e do real no texto fantástico:

Suspeitamos constantemente do autor. Enganarnos é a sua função; sabemos que ele quer fazernos acreditar em coisas que estão em flagrante contradição com a nossa própria experiência da realidade. Estamos prontos a duvidar de todas as suas palavras. Ao longo do texto, a sua perícia e o nosso cepticismo lutam furiosamente... Se o autor puder incorporar na sua narrativa excertos de alguma "autoridade" respeitada, o nosso cepticismo diminui. Embora saibamos que tais excertos não Ihes dão qualquer apoio real, impressiona encontrar as afirmações do autor aparentemente confirmadas por uma fonte tão digna de confiança. (Apud FURTADO, 1980, p.54) 
De acordo com Filipe Furtado, alguns elementos funcionam como recurso à autoridade no texto fantástico. 0 primeiro deles é a personagem. Para suscitar um "efeito de real", ou melhor, constituir um recurso à autoridade, esta figura precisa ocupar um posto respeitável na sociedade, seja naquela construída na diegese seja na conhecida pelo leitor da obra. Em grande parte das narrativas que fazem uso desse recurso, tais figuras são apresentadas como médicos, advogados, professores universitários. Em suma, são pessoas que representam uma área do saber, principalmente científico.

Além da credibilidade atribuída a certas personagens, o crítico português também considera a credibilidade atribuída a certos objetos, tais como a descoberta de documentos, um livro antigo, entre outros, o que também concorre para o efeito de realidade. Ainda segundo Furtado (1980, p.56), para "incrementar a sua plausibilidade, a narrativa fantástica também recorre amiúde ao que se pode denominar referências factuais, alusões mais ou menos extensas e profundas a factos ou fenômenos do mundo empírico inteiramente comprováveis". Conforme o estudioso, as referências factuais se dividiriam em duas: 1) acontecimentos históricos ou fatos contemporâneos referentes à sociedade na qual a personagem ou o leitor estão inseridos. 2) dados científicos ou pseudocientíficos, também adequados à realidade da diegese ou do leitor.

Por fim, são expostos mais dois recursos comumente utilizados na narrativa fantástica. O primeiro deles é o testemunho de um narrador personagem, principalmente daquele que se mostra cético perante os acontecimentos sobrenaturais, aplicando-se às mesmas regras trabalhadas na categoria de personagens já expostas. O 
segundo é a explicação racional de recursos secundários, tais como o deslocamento da ação da história no tempo, chamado de "efeito de recuo", ou a "confirmação pseudocientífica" de elementos sobrenaturais que permeiam o discurso fantástico, causando a falsa impressão de realidade presente na narrativa. Dessa forma, apesar de Filipe Furtado, em nenhum momento, citar o texto de Roland Barthes, fica clara a aproximação entre os recursos à autoridade explicitados pelo teórico português e os efeitos de real teorizados pelo crítico francês. De tal modo, mesmo separados geográfica e cronologicamente, os dois estudiosos estabelecem uma profícua parceria para o estudo do fantástico.

\section{O EFEITO FANTÁSTICO EM THE PRESTIGE}

Em um primeiro momento, faz-se necessário indicar duas obras da literatura que serão trabalhadas neste tópico a título de comparação e exemplificação do efeito fantástico. São elas $A$ outra volta do parafuso (1898), de Henry James, e "O chamado de Cthulhu" (1928), de H. P. Lovecraft. Ambas as narrativas se destacam, principalmente, pelos artifícios utilizados a fim de ludibriar o leitor e levá-lo ao ponto central do efeito fantástico: a hesitação. Para isso, faremos uma breve apresentação de cada obra a fim de situar o leitor.

A outra volta do parafuso conta a história de uma preceptora, filha de um pároco, que aceita a oferta de se mudar para Bly para cuidar de duas crianças órfãs, sobrinhas de seu empregador. Ao chegar ao emprego de seus sonhos, a preceptora, que não é nomeada em nenhum momento da novela, percebe estranhas movimentações na propriedade. A seus olhos, tais movimentações 
estarão intimamente atreladas aos fantasmas dos antigos funcionários da casa, os quais morreram sob circunstâncias suspeitas. Esses acontecimentos levam-na a embarcar em uma viagem sem volta na tentativa de proteger as crianças das influências malignas de tais fantasmas, os quais, segundo sua percepção, queriam corrompê-las. Tal obsessão se torna tão profunda que, ao final da história, Flora, a mais nova, precisa ser mandada embora da propriedade, pois se sentia ameaçada pela preceptora, e Miles, o mais velho, morre também sob circunstâncias suspeitas após a mulher avistar um dos fantasmas e tentar forçá-lo a aceitar a aparição. O que acrescenta e transforma essa narrativa é o início da novela. É precisamente nos primeiros parágrafos que descobrimos que essa história fora escrita pela própria preceptora e entregue ao personagem Douglas. Este iria reproduzi-la, em uma véspera de natal, para uma plateia interessada em contar e ouvir histórias de terror.

"O chamado de Cthulhu" apresenta-se como um "metamanuscrito", pois, antes mesmo da história começar a ser narrada, somos informados que tal texto fora "encontrado entre os papéis do falecido Francis Wayland Thurston, de Boston" (LOVECRAFT, 2015, p.1), o qual se mostra como o protagonista da história nos parágrafos seguintes. A partir desse ponto, seguimos a obsessão crescente sobre um culto desconhecido pelo protagonista após este receber os pertences de seu tio-avô e, dentre eles, encontrar uma estátua de argila com um formato nunca antes visto por ele. A partir de tal obsessão, somos levados a acompanhar o protagonista em sua busca por mais informações sobre aquela figura, mergulhando em uma onda de documentos e testemunhas 
encontradas pelo caminho no decorrer da narrativa. Ao fim, somos informados do total convencimento do narrador da existência dessa criatura mitológica e monstruosa, porém, por conta de tudo que foi descrito, das situações que ele viveu, o leitor é levado a ponderar se pode realmente acreditar na palavra de tal confidente.

A partir do exposto, verifica-se uma similaridade entre as duas obras literárias e o filme aqui analisado: a presença de manuscritos como meio de contar uma história. Em A outra volta do parafuso, temos o manuscrito da preceptora, escrito por ela após todos os supostos acontecimentos em Bly. Em O chamado de Cthulhu, além da própria história ser apresentada como um manuscrito encontrado entre os papéis de um homem morto, seu enredo só se desenvolve, em grande parte, por conta de relatos escritos encontrados a fim de tentar preencher as lacunas daquele mistério. Em The Prestige, somos levados a acompanhar grande parte da história a partir das leituras dos diários de Angier e Borden. O manuscrito, usado como um argumento de autoridade, citado por Furtado, faz-se presente nas três narrativas, de forma a contribuir com a primeira fagulha do efeito fantástico em cada uma das obras. Assim, observamos no filme de Christopher Nolan uma utilidade dupla para os diários, como aponta Todd McGowan (2007, p. 19-20):

The device through which Nolan shifts the time period in the film is often (though not exclusively) the diaries of Borden and Angier. The narrative moves as either Borden or Angier reads the other's diary. The use of the diary as a vehicle for temporal shifts has the effect of emphasizing the mediated-and thus deceptive-nature of the events depicted in the film. The film never simply lays its cards on the table: even when 
it appears to do so, it does so for the sake of furthering its deception. This is especially true in the use of the diary as means for moving in time within the narrative. [...] By using the diary as a narrative device, a fictional work like a film or a novel can insinuate its truthfulness and, to some extent, obscure its fictionality. The use of the diary in The Prestige, however, operates in the other direction. Rather than permitting the diary to validate the veracity of the filmic illusion, The Prestige as a fiction works to impugn the truthfulness of the diary as such. The only type of diary that the film envisions is a diary written for the purpose of deception or frustration. ${ }^{3}$

Como McGowan aponta, a intenção falaz do uso do diário como elemento de enganação funciona em um caminho duplo. Ao mesmo tempo em que Angier e Borden se enganam com as leituras dos diários, também Christopher Nolan engana o espectador, levando-o a um caminho que mais tarde se mostrará infrutífero. Assim como no truque de mágica, Nolan desvia a atenção do espectador para o caminho oposto ao qual o verdadeiro truque está acontecendo. Enquanto o mágico mostra uma mão vazia, a outra está na direção oposta trabalhando para a ilusão funcionar.

3 Tradução: O dispositivo pelo qual Nolan alterna o tempo narrativo no filme é, constantemente (mas não exclusivamente), os diários de Borden e Angier. A narrativa avança conforme Borden ou Angier leem os diários uns dos outros. O uso do diário como uma forma de mudança temporal tem o efeito de dar ênfase à natureza mediada - e ainda assim enganosa - dos eventos retratados no filme. O filme nunca simplesmente coloca as cartas na mesa: mesmo quando parece que o faz, faz para conseguir alcançar uma enganação futura. Isso fica evidente no uso do diário como um meio de mover-se pelo tempo dentro da narrativa. [...] Ao usar o diário como uma ferramenta narrativa, uma obra ficcional como um filme ou um romance pode insinuar sua veracidade e, até certo ponto, obscurecer sua ficcionalidade. O uso do diário em The Prestige, entretanto, opera de forma contrária. Ao invés de permitir que o diário valide a veracidade da ilusão fílmica, The Prestige, como uma ficção, trabalha para contestar a veracidade do diário como tal. O único tipo de diário que o filme retrata é um diário escrito com a intenção de enganar ou frustrar (tradução nossa). 
Assim ocorre também, porém em um nível assaz mais subjetivo, nas obras de Lovecraft e Henry James, ao trabalharem com manuscritos que foram redigidos por figuras que não podem ser consideradas perfeitamente estáveis quanto à sanidade mental. Como McGowan (2007, p.20) afirma mais à frente em seu artigo: "The diary form, as the film conceives it, is nothing but a mode of seducing the other with the allure of a private moment of nonfiction. The nonfiction form of the diary simply makes it a more effective fiction in relation to the audience" ${ }^{\prime \prime}$.

Outra característica muito presente nas narrativas fantásticas, e que se mostra pertinente para a construção do filme de Nolan, é a estrutura narrativa fragmentada. Em A outra volta do parafuso, temos, primeiramente, o espaço em que Douglas se reúne com outras pessoas enquanto elas contam histórias de fantasmas. Após sermos introduzidos nesse meio a partir de um narrador homodiegético, somos levados a adentrar a história da preceptora, a partir de um narrador autodiegético. Tal fragmentação também ocorre, até de forma mais acentuada, em O chamado de Cthulhu, no qual, após ser indicado ao leitor que aquilo que ele está lendo é apenas um manuscrito encontrado dentre os papéis de um homem morto, somos levados a, junto do protagonista, encontrar outras "peças" perdidas daquele quebra-cabeça para tentar entender a história. Da mesma forma ocorre, como já explicitado, em The Prestige, quando Nolan expõe cortes temporais na narrativa fílmica sem qualquer marcação. Ao transitar entre o presente e o passado,

4 Tradução: A forma de diário, como o filme a concebe, não é nada senão um modo de seduzir o outro com o fascínio de um momento privado de não ficção. A forma de não ficção do diário simplesmente torna uma ficção mais efetiva com relação ao público (tradução nossa). 
o diretor consegue chamar a atenção do espectador, principalmente para prendê-lo naquilo que não é realmente importante, de modo que fique mais fácil causar a ilusão proposta por seu filme. Tal elemento se mostra pertinente para a constituição do efeito fantástico, principalmente por conta da confusão causada e da forma convidativa que se mostra ao leitor/expectador, propondo que este participe ativamente da narrativa. Tal imersão se mostra essencial, seja para o efeito catártico supostamente pretendido por Nolan ao final do filme, seja para gerar a hesitação nas narrativas aqui descritas. Um leitor/espectador que não participe efetivamente da obra não pode experimentar a hesitação ou a catarse.

Uma característica que é extremamente trabalhada em The Prestige, e que também aparece de maneira pungente na novela de Henry James, é a temática do duplo. Apesar de não estar intrinsecamente ligada ao efeito fantástico, tal tema pode contribuir muito para sua construção, visto que, geralmente, transpõe a ideia de dubiedade, de dicotomia. Em A outra volta do parafuso, percebemos diversos elementos que se encaixam nessa temática, desde o espaço, com as duas torres muito parecidas do casarão, até as relações entre as próprias personagens, visto que eram dois empregados que se tornaram fantasmas. Também são duas crianças a serem cuidadas, há duas mulheres adultas que protagonizam a história, além do caráter dual da personalidade da preceptora, que ora vê as crianças como anjos, ora as vê como possuídas pelos próprios fantasmas.

No filme de Christopher Nolan, tal temática está muito presente e evidente. São diversos os elementos que se encaixam nesse viés analítico, como a rivalidade eterna entre Borden e Angier, os canários 
idênticos usados para os truques de mágica, o irmão gêmeo de Borden que decidiu viver uma vida única com o irmão enquanto se alternavam, as duplicações de Angier, etc. A lista é longa. Tais elementos levam o leitor/espectador a ter um sentimento dúbio. Ao mesmo tempo que ele parece precisar tomar uma decisão, isso não acontece, pois há tantas dúvidas com relação aos acontecimentos ali relatados, seja no filme, seja nas narrativas, que é impossível realmente fazer uma escolha. Tal situação revela o verdadeiro poder do efeito fantástico, o qual coloca o leitor em posição de ter duas ou mais possibilidades de escolha para "acreditar", mas que não pode se decidir, não consegue, pois não há um único elemento concreto que o guie para uma ou outra, são todos superficiais. Tal leitor vive eternamente - em alguns casos - em um limbo, no qual vê a possibilidade, o caminho para sair, mas não consegue se movimentar.

Christopher Nolan ainda vai além, ao fazer uso da maquiagem para esconder Fallon - assistente de Borden - que aparece rapidamente em algumas cenas. Sem nunca haver um enfoque direto em seu rosto, ele se esconde à plena vista, por mais paradoxal que isso possa parecer. A fotografia e a representação do espaço também foram uma escolha importante para manter uma atmosfera de mistério, visto que a história se passa na Era Vitoriana e grande parte dos acontecimentos se desenrolam apenas à noite. As ruas de Londres são usadas para esconder tanto os segredos de Angier e Borden quanto os de Nolan. Até a música se mostra como elemento mantenedor dos aspectos aqui abordados, como exposto por Batista (2012, p. 94):

O uso da música é outro recurso que o filme se utiliza para construir sua atmosfera de mistério e fantasia. 
A música é quase sempre discreta, mas sempre acompanha o tom da cena, destacando, pontuando e acentuando os momentos de mistério, tensão, mas também os de emoção e de triunfo. A função da música no filme é similar a da mágica, uma vez que os mágicos, inclusive aqueles retratados no filme, se usam da música para destacar certos momentos de suas apresentações, como o rufar de tambores nos momentos de expectativa ou um acorde mais cômico para realçar uma ação de humor.

O filme de Nolan é repleto de elementos que corroboram, principalmente, com a temática do duplo, traçando, simbolicamente, um caminho a ser seguido do início ao fim da história. Indica-se, portanto, as inúmeras possibilidades interpretativas que pesquisas a respeito do filme The Prestige revelam, principalmente por conta de sua estrutura fragmentada e densidade simbólica. Conclui-se que os elementos até aqui apresentados se relacionam diretamente com o estado de suspensão em que o leitor, sob o efeito fantástico, é colocado ao assistir o filme. É possível perceber, portanto, que a partir de sua habilidade com o ferramentário cinematográfico, Christopher Nolan conseguiu transformar uma história que poderia ser considerada um clichê em um filme com características únicas e indistinguíveis. O cineasta proporciona ao espectador sentir como se estivesse lendo uma novela de Henry James ou um conto de H. P. Lovecraft. Faz com que ele esteja sob o efeito fantástico.

\section{REFERÊNCIAS}

ALVAR, Farzad Kolahjooei (2017). Christopher Nolan and the Art of Anamorphosis. Tese (Doutorado em Filosofia). Universidade de Waterloo, Ontario, Canadá.

BARTHES, Roland (2004). O Efeito de Real. In: O rumor da língua. São Paulo: Martins Fontes. 
BATISTA, Lucas Ravazzano de Mattos (2012). Mágica, sonho e lembrança: o cinema de Christopher Nolan. Dissertação (Mestrado em Comunicação). Universidade Federal da Bahia, Salvador.

FURTADO, Filipe (1980). A construção do fantástico na narrativa. Lisboa: Livros Horizonte.

JAMES, Henry (2010). A outra volta do parafuso. São Paulo: Abril.

LOVECRAFT, Howard Phillips (2015). O chamado de Cthulhu. São Paulo: Hedra. MCGOWAN, Todd (2007). "The violence of creation in The Prestige". In: International Journal of Zizek Studies, (1)3. In http://zizekstudies.org/index.php/ IJZS/article/view/49/46 Acesso em 17.Dez.2017.

NOLAN, Christopher (2006). The Prestige (2006). Christopher Ball e outros (Produção). Los Angeles: Warner Brothers. 1 DVD (130 min), widescreen, color. ROAS, David (2014). A ameaça do fantástico: aproximações teóricas. Julián Fuks (Trad.). São Paulo: Editora Unesp.

SANTOS, Hilario Junior dos (2017). "O mágico cineasta e o prestígio: narrativa, metalinguagem e tecnologia no cinema espetáculo". In: Intercom - Sociedade Brasileira de Estudos Interdisciplinares da Comunicação, Chapecó. In http:// www.intercom.org.br/papers/regionais/sul2012/resumos/R30-0243-1.pdf. Acesso em: 15.Dez.2017. 